\title{
HESS Opinions: A planetary boundary on freshwater use is misleading
}

\author{
Maik Heistermann \\ Institute of Earth and Environmental Science, University of Potsdam, 14476 Potsdam, Germany \\ Correspondence to: Maik Heistermann (heisterm@uni-potsdam.de)
}

Received: 27 February 2017 - Discussion started: 7 March 2017

Revised: 7 June 2017 - Accepted: 9 June 2017 - Published: 12 July 2017

\begin{abstract}
In 2009, a group of prominent Earth scientists introduced the "planetary boundaries" (PB) framework: they suggested nine global control variables, and defined corresponding "thresholds which, if crossed, could generate unacceptable environmental change". The concept builds on systems theory, and views Earth as a complex adaptive system in which anthropogenic disturbances may trigger nonlinear, abrupt, and irreversible changes at the global scale, and "push the Earth system outside the stable environmental state of the Holocene". While the idea has been remarkably successful in both science and policy circles, it has also raised fundamental concerns, as the majority of suggested processes and their corresponding planetary boundaries do not operate at the global scale, and thus apparently lack the potential to trigger abrupt planetary changes.

This paper picks up the debate with specific regard to the planetary boundary on "global freshwater use". While the bio-physical impacts of excessive water consumption are typically confined to the river basin scale, the PB proponents argue that water-induced environmental disasters could build up to planetary-scale feedbacks and system failures. So far, however, no evidence has been presented to corroborate that hypothesis. Furthermore, no coherent approach has been presented to what extent a planetary threshold value could reflect the risk of regional environmental disaster. To be sure, the PB framework was revised in 2015, extending the planetary freshwater boundary with a set of basin-level boundaries inferred from environmental water flow assumptions. Yet, no new evidence was presented, either with respect to the ability of those basin-level boundaries to reflect the risk of regional regime shifts or with respect to a potential mechanism linking river basins to the planetary scale.
\end{abstract}

So while the idea of a planetary boundary on freshwater use appears intriguing, the line of arguments presented so far remains speculative and implicatory. As long as Earth system science does not present compelling evidence, the exercise of assigning actual numbers to such a boundary is arbitrary, premature, and misleading. Taken as a basis for waterrelated policy and management decisions, though, the idea transforms from misleading to dangerous, as it implies that we can globally offset water-related environmental impacts. A planetary boundary on freshwater use should thus be disapproved and actively refuted by the hydrological and water resources community.

\section{The planetary boundaries framework}

In 2009, a group of prominent scientists led by Johan Rockström introduced the "planetary boundaries" (PB) framework (Rockström et al., 2009a, b). They identified nine Earth system processes - climate change, rate of biodiversity loss, interference with the nitrogen and phosphorus cycles, stratospheric ozone depletion, ocean acidification, global freshwater use, land use change, chemical pollution, and atmospheric aerosol loading -, each of which is represented by a control variable. Accordingly, planetary boundaries are defined as "thresholds [of these control variables] which, if crossed, could generate unacceptable environmental change". Moving outside this "safe operating space for humanity" may be "deleterious or even catastrophic for human well-being."

\footnotetext{
${ }^{1}$ Not to be confused with the meteorological term "planetary boundary layer", i.e. the lowest part of the atmosphere.
} 
At its heart, the PB framework builds on systems theory. It views Earth as a complex adaptive system in which anthropogenic disturbances may trigger non-linear, abrupt, and irreversible changes at the global scale, and "push the Earth system outside the stable environmental state of the Holocene". Furthermore, Rockström and colleagues refer to concepts such as limits to growth (Meadows et al., 2004), safe minimum standards (Crowards, 1998), the precautionary principle (Raffensperger and Tickner, 1999), and tolerable windows (Petschel-Held et al., 1999).

The success of the PB framework has been remarkable in both scientific and policy arenas. Since 2009, the two original papers together have been cited more than 2000 times in scientific journals tracked by Thomsen Reuters's Web of Science, and are still gaining traction. The PB concept has been embraced by the United Nations High-Level Panel on Global Sustainability (2012) and non-governmental organizations such as the World Wildlife Fund for Nature (2016). It was included in the Global Environment Outlook 5 (United Nations Environment Programme, 2012), and underpins a reform proposal for global environmental institutions by the Earth System Governance Project (Biermann et al., 2012). In April 2017, a large international conference on "Making the Planetary Boundary Concept Work" was hosted by the German government, namely the Federal Ministry for the Environment, Nature Conservation, Building, and Nuclear Safety and the Federal Environment Agency (Umweltbundesamt).

The PB framework is founded on the assumption that transgressing any of the planetary boundaries may induce irreversible changes at the global scale. In this paper, I will argue that the definition of a corresponding planetary boundary on freshwater use is not only scientifically weak, but also misleading and potentially dangerous if operationalized in a policy context. It should thus be disapproved and actively refuted by the hydrological and water resources community.

\section{Previous debate}

The PB framework was quickly picked up in the scientific discourse. Critical commentaries, however, mostly called for a revision of the actual numbers (e.g. Molden, 2009; Destouni et al., 2013; Jaramillo and Destouni, 2015). Compared to the widespread endorsement of the PB framework, fundamental criticism has been scarce. Only a few authors insisted that the majority of the suggested processes and their corresponding planetary boundaries do not operate at the global scale, and thus do not have the potential to trigger abrupt planetary changes. Accordingly, Lewis (2012) concluded that "there is no need for all the world's countries to enter protracted legal discussions on aggregate boundaries: those affected by regional problems should work among themselves to solve them. Global negotiations should focus on managing the clear planetary boundaries of climate change and ocean acidification [...]". Nordhaus et al. (2012) argued that "six of the planetary boundaries [...] do not have planetary biophysical thresholds [...] and operate on local to regional, not global, levels." They warn that "global limits may risk misleading local and regional policy choices".

In order to safeguard against such concerns, the original paper by Rockström et al. (2009a) had already distinguished between "boundaries that are directly related to sharp continental or planetary thresholds [...], and boundaries based on 'slow' planetary processes with no current evidence of planetary scale threshold behavior [... ]". Interestingly, the admitted lack of evidence did not keep the authors from defining the corresponding planetary thresholds, hypothesizing that these "may arise at the local and regional scales, which become a global concern at the aggregate level."

Resulting from a continued discourse, Steffen et al. (2015) published a revised version of the PB framework in Science, updating most of the boundary estimates, but also trying to consider some of the more fundamental criticism. Most importantly, the revision introduces "a two-tier approach for several of the boundaries to account for regional-level heterogeneity" (see next section). Furthermore, Steffen et al. (2015) repeatedly insist on the necessity to define planetary boundaries for all of the processes included in the framework, e.g. claiming that "[...] not all Earth-system processes included in the PB approach have singular thresholds at the global/continental/ocean basin level. Nevertheless, it is important that boundaries be established for these processes [...] [such as freshwater use]. Placing boundaries for these processes is more difficult [...] but is nevertheless important for maintaining the resilience of the Earth system as a whole."

In the following section, both the original and the revised version of the framework will be discussed with specific regard to the planetary boundary on freshwater use.

So far, the hydrological community has remained quite silent in the controversy about the scientific justification of the PB framework. The discourse did not take place in "traditional" hydrology or water resources journals. Freshwater use is, however, at the heart of hydrological science and water resources management, and it is about time for the community to take a stand towards a corresponding planetary boundary.

\section{The planetary boundary on freshwater use}

Rockström et al. (2009a, b) suggested that global freshwater consumption (from rivers and groundwater bodies) by humans must not exceed $4000 \mathrm{~km}^{3}$ year $^{-1}$, while the current level of that control variable was estimated at a level of $2600 \mathrm{~km}^{3}$. These figures remained essentially unchanged in the update by Steffen et al. (2015). Accordingly, the current level of human freshwater appropriation is still considered to be "safe" (see Fig. 1). 


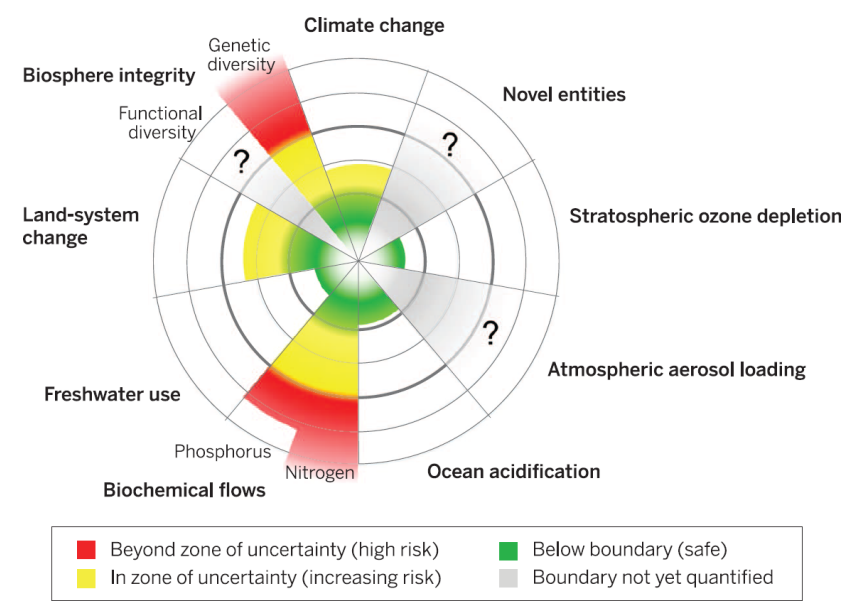

Figure 1. According to the latest revision of the PB framework, humanity is still "in the green" with regard to freshwater use; from Steffen et al. (2015), reprinted with permission from AAAS.

While such a conclusion might be doubted by those billions of people already exposed to water scarcity, I intend to question neither the estimate of the boundary nor the estimate of the control variable's current value, but the concept of a planetary freshwater boundary itself.

Generally, we expect environmental impacts of consumptive freshwater use to be confined to the river basin scale. Exceptions are e.g. with interbasin water transfer schemes (Zhuang, 2016) and system collapses such as the Aral Sea Disaster, for which the biophysical and socioeconomic impacts could, in fact, be felt at a regional scale beyond the watershed (Micklin, 2007). It is that kind of regional regime shift that the PB proponents most likely had in mind. Yet, they do not corroborate how such a collapse could push the entire Earth system away from its Holocene state. Such a planetary feedback would only be conceivable through mechanisms in the climate system. And, truly, terrestrial moisture recycling is a mechanism that can link regions far apart from each other - beyond watersheds, and potentially across continents (van der Ent et al., 2010). It replenishes, through terrestrial evapotranspiration, the moisture flux that is directed from the oceans into the continents, and thus sustains downwind rainfall. Hence, there is growing concern that e.g. large-scale deforestation might fundamentally disrupt moisture recycling (e.g. Boers et al., 2017). However, the dynamic role of local coupling and changes in the atmospheric circulation is yet to be understood. Accordingly, Goessling and Reick (2011) warned that "moisture recycling estimates cannot consistently be used as reliable indicators for the sensitivity of precipitation to modified land-evaporation".

But while there is at least credible evidence that deforestation could disrupt regional water cycles, the role of consumptive freshwater use, e.g. by irrigation, remains largely unclear: a number of studies suggest that irrigation intensifies terrestrial soil moisture recycling, and thus increases down- wind precipitation (e.g. DeAngelis et al., 2010; Puma and Cook, 2010; Jódar et al., 2010; Harding and Snyder, 2012; Zou et al., 2014; Alter et al., 2015). Others suggest that irrigation affects local rainfall, too: irrigation-induced surface cooling could increase local atmospheric stability, and thus reduce local rainfall (Lee et al., 2009; Guimberteau et al., 2012; Im et al., 2014; Tuinenburg et al., 2014). Or, irrigation could increase convective available potential energy and precipitable water, and thus increase local rainfall (Mahalov et al., 2016). Irrigation-induced changes in local precipitation are mostly tied to changes in large-scale moisture convergence, and thus to changes in precipitation elsewhere. Besides, local and downwind effects can occur simultaneously (Pei et al., 2016). Im and Eltahier (2014) even detected, in a simulation experiment, a constellation in which irrigation increased rainfall (by 100\%) and runoff (by 50\%) in the Niger River basin upstream from the irrigation location.

What all of these studies demonstrate, together, is that the complex interaction of different atmospheric and surface processes is as yet poorly understood. What none of these studies demonstrates, though, is how freshwater use would cause the collapse of regional or continental hydrological cycles. Accordingly, neither Rockström et al. (2009a) nor Steffen et al. (2015) have presented evidence to support their claim that "water-induced thresholds at the continental or planetary scale may be crossed as a result of aggregate subsystem impacts at local (e.g., river basin) or regional (e.g., monsoon system) scales caused both by changes in water resource use and climate change-induced shifts in the hydrological cycle". Instead, the line of argument remains implicatory when it refers, in the section on global freshwater use, to studies on wet-to-dry state shifts of the Sahel zone (Scheffer et al., 2001; Foley et al., 2003) and the "savannization" of the Amazon (Oyama and Nobre, 2003) - none of which considers freshwater consumption as a driving force.

But even if we assumed, for a moment, the validity of the hypothesis that human freshwater use could trigger regionalscale shifts which in turn would build up to planetary-scale feedbacks and system failures, how could a planetary boundary on freshwater use reflect such regional thresholds? Obviously, it could not.

This realization motivated the extension of the PB framework by Steffen et al. (2015) in order to "capture the importance of subglobal change for the functioning of the Earth system". It is crucial to understand that this extension does not aim at merely representing the spatial heterogeneity of environmental stress, but also at detecting regional environmental stress that could feed back to the planetary scale: "We emphasize that our subglobal-level focus is based on the necessity to consider this level to understand the functioning of the Earth system as a whole."

Steffen and colleagues maintained the planetary freshwater boundary on "consumptive blue water use $\left(\mathrm{km}^{3} \mathrm{year}^{-1}\right)$ " at a level of 4000-6000 $\mathrm{km}^{3} \mathrm{year}^{-1}$, but they added "a basinscale boundary for the maximum rate of blue water with- 
drawal along rivers, based on the amount of water required in the river system to avoid regime shifts in the functioning of flow-dependent ecosystems." That control variable is based on the concept of environmental water flows, and had originally been proposed by Gerten et al. (2013) in the PB context. Yet again, no evidence is presented that those thresholds actually serve their designated purpose within the PB framework ("... to understand the functioning of the Earth system as a whole."). It is not even exemplarily verified that exceeding such a basin-level threshold could trigger regional regime shifts, and least of all how such regional shifts could build up to a planetary feedback. What remains, between the lines, is the mere implication that reservations towards a single "planetary freshwater boundary" have been taken care of. Still, the actual relationship between the "planetary freshwater boundary" and its basin-level counterpart remains vague: Gerten et al. (2013) had originally upscaled the basin-level freshwater boundaries to a single planetary freshwater boundary of $1100-4500 \mathrm{~km}^{3}$ year $^{-1}$. But just as Gerten et al. (2013) had not elaborated on the need to aggregate their estimate to a single global number, Steffen et al. (2015) did not explicate why they did not aggregate the basin-level boundaries but rather stuck with the original planetary boundary value.

Summing up, the revised framework maintains global freshwater use as a planetary boundary, prominently displayed in the main figure of the Science paper (Fig. 1), and widely disseminated thereafter. According to that figure, humanity is still "in the green" with regard to freshwater consumption. In order to rebut concerns regarding such a planetary boundary, Steffen et al. (2015) suggested an additional boundary on freshwater withdrawal at the basin scale, the role of which in the entire PB framework remains vague, and which is not supported by any new evidence.

\section{The context of global water governance}

For a broader view of the issue, it should be noted that the idea of a planetary freshwater boundary is, intentionally or not, well in line with other concepts implying that water resources could and should be globally managed. The most prominent of these concepts is the water footprint, originally suggested by Hoekstra and Hung (2002). The water footprint is defined "as the total volume of freshwater used to produce the goods and services consumed by the individual or community [such as a nation or humanity]" (Hoekstra et al., 2011). From early on, it had been a deliberate decision to make the water footprint a measure of water use only, and not to consider water availability at the location in which the water is actually used. The rationale behind that decision is that water is considered a globally scarce resource. Accordingly, reducing the water footprint is generally seen as a desirable outcome irrespective of local water scarcity. That notion has attracted fierce criticism (Gawel and Bernsen, 2013; Perry, 2014; Wichelns, 2010, 2011 - to name only a few), the consequences of which are, however, nil: since 2006, more than 700 articles have been published on the topic of "water footprint", with a total citation count of more than 10000 (still exponentially increasing). Similar to the PB framework, the concept has been embraced by the scientific community, by national governments, by nongovernmental organizations such as the World Wildlife Fund For Nature, and also by multinational corporations such as Coca Cola, Nestlé, or Unilever. The proponents continue to emphasize that "[...] reducing water footprints in waterstressed catchments displays a limited perspective on the question of what is globally sustainable [...]", and that "the world's [...] freshwater resources are accessible from anywhere through trade in water-intensive commodities" (Hoekstra and Mekonnen, 2012). The latter notion is one of the key arguments in the call for "global water governance" (Hoekstra, 2011; Vörösmarty et al., 2015), based on the hypothesis that virtual water trade makes water a global resource that, through trade interventions, could be arbitrarily redistributed across basins. This view, however, has been repeatedly refuted (e.g. Gawel and Bernsen, 2013; Wichelns, 2015): while a globalized trade in fact "transports" substantial volumes of virtual water across the globe (Dalin et al., 2012), policy and management choices should be made by the affected stakeholders instead of being imposed by whatever water-related global trade mechanism.

It would surely be worthwhile, in another paper, to provide a comprehensive synopsis of the water footprint debate and its links to the controversy on the planetary freshwater boundary. Both have entirely different motivations: the freshwater PB is about critical environmental limits to water use, while the water footprint is about the actual magnitudes of that use. Yet, both share the implication that the world requires global water governance - a global regulation of water consumption. Meanwhile, the same world still awaits the first evidence that either of the two concepts has yet provided any useful guidance to those actors on the ground who struggle for the sustainable management of an increasingly scarce resource.

\section{Conclusions}

The PB concept can be viewed from two perspectives: first, as a scientific framework that is built on systems theory, and second, as a guide towards sustainable development and resource management. The planetary boundary on freshwater use fails in both regards.

From a scientific perspective, the existence of such a boundary is mere speculation. The proponents argue that local freshwater consumption could lead to regional system collapses which could in turn build up ("across scales”) to irreversible state shifts at the global level. While the thought itself is intriguing, the line of arguments presented so far remains implicatory. And as long as Earth system science does 


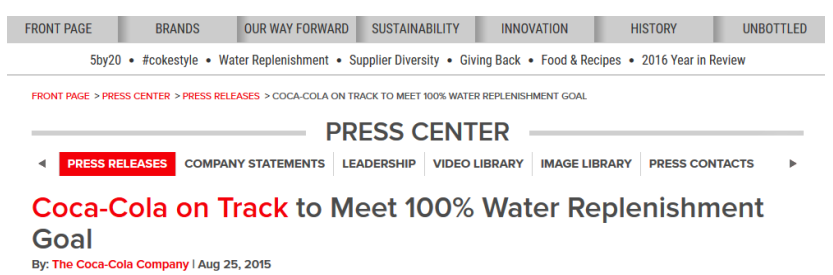

Figure 2. Screenshot of an online press release from $25 \mathrm{Au}-$ gust 2015 (Coca Cola Company, 2015). In this press release, the Coca Cola Company claims to be close to "water neutral". For this purpose, water use related to the production process is offset ("replenished") by conservation efforts around the globe. The press release was quickly and mostly uncritically picked up by various media channels, e.g. the New York Times online edition.

not present compelling evidence, the exercise of assigning actual numbers to such a boundary is arbitrary, premature, and misleading. It is misleading in multiple respects: it pretends to a level of understanding that is non-existent, and it suggests that reducing global water consumption mitigates regional water issues.

Still, one might argue that it is worth sacrificing some scientific rigour if the framework could at least pragmatically guide us towards sustainable water resources management. In that regard, however, it fails even more obviously. Today, there is no robust evidence how water management in one basin would physically affect other basins across the world, and it is unsettling to see that scientists and policymakers are starting to take that narrative seriously nonetheless. As Lewis (2012) put it, the idea is "politically seductive". However, taken as a basis for water-related policy and management decisions, it is misleading and potentially dangerous. It suggests that we can globally offset water-related environmental impacts, a notion that defies both common sense and hydrological science. The potential consequences of such reasoning are exemplified in Fig. 2. While I believe that such ideas were not originally intended by Rockström and colleagues, a planetary boundary on freshwater use remains a point-blank invitation to promote ideas such as "water neutrality" or "water offsetting".

Admittedly, the precautionary principle (Raffensperger and Tickner, 1999) can always be considered a safeguard against an alleged "lack of scientific evidence". But before kicking off another debate as to whether the hypothesis of a "planetary freshwater boundary" qualifies for a "minimal threshold of plausibility" (van den Belt, 2003), we might find that stressing the precautionary principle simply misses the point: the impacts of water scarcity on human welfare are already obvious, felt every day by the very people living in water scarce regions. Contemplating the applicability of the precautionary principle to the issue of freshwater use might, to those people, appear like a discussion from a parallel universe.

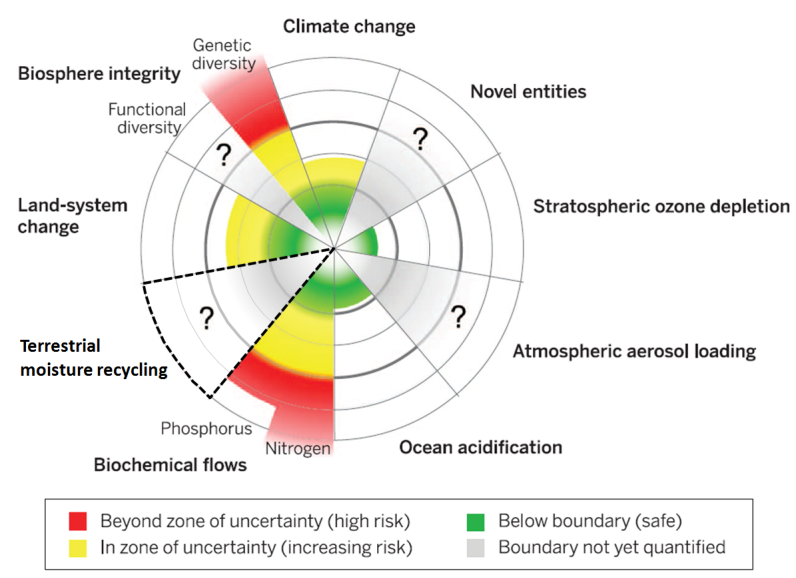

Figure 3. An example of how a water-related planetary boundary could be explicit with regard to both the mechanism of interest and our lack of understanding it; modified from Steffen et al. (2015), with permission from AAAS.

Given the intensity of that criticism, it appears legitimate to inquire about the original motives to include a process such as freshwater use in a framework on planetary boundaries. Maybe the sheer significance of water - as a key component of the Earth system and as a sustainable development challenge - made it agreeable to tacitly ignore hydrological fundamentals? While the key literature on planetary boundaries does not answer that question, the interactive discussion related to this opinion article (http://www.hydrol-earth-syst-sci-discuss. net/hess-2017-112/\#discussion) sheds some light on the motives. There, Johan Rockström argues that the planetary boundary on freshwater use actually "has nothing to do with human water use [but] with the maximum level of shifts in the global hydrological cycle [...]".

So, is the present controversy just a matter of terminology? Indeed, Rockström's surprising notion calls, at least, for a fundamental revision of the freshwater PB, starting with a definition that is explicit and transparent with regard to the underlying mechanism: if, for example, the disruption of terrestrial moisture recycling was considered critical, that notion should be clearly reflected by the definition of any waterrelated boundary. Still, it would be a long way from there to convey the required quantitative evidence whether and at which point that process might "push the Earth system outside the stable environmental state of the Holocene". Until then, the PB community should withstand the temptation to (expert) guess numbers, and instead be as explicit about the fundamental knowledge gap as it should be about the underlying mechanism. Figure 3 is a mere example of how such explicitness could be conceived.

But while the need to fundamentally revise the planetary boundaries framework is obvious, the complete package has gained so much traction that it already appears to be be- 
yond fundamental scrutiny. Still, the hydrological community should not just give in. Instead, we should actively engage in refuting and pushing back the misconception that a global threshold on freshwater use can have any meaningful policy implications, and stop giving scientific credibility to that framework until substantial evidence is presented.

Data availability. No data sets were used in this article.

Competing interests. The author declares that he has no conflict of interest.

Acknowledgements. I would like to thank those who participated in the interactive discussion of this paper, namely Murugesu Sivapalan, Christof Lorenz, Fernando Jaramillo, Hubert H. G. Savenije, Dieter Gerten, Chris Perry, Johan Rockström, and an anonymous referee. In my opinion, that interactive discussion provides lots of additional insights, and I sincerely recommend it to any interested reader: http://www.hydrol-earth-syst-sci-discuss.net/ hess-2017-112/\#discussion.

Edited by: Erwin Zehe

Reviewed by: Dieter Gerten, Hubert H. G. Savenije, and one anonymous referee

\section{References}

Alter, R. E., Fan, Y., Lintner, B. R., and Weaver, C. P.: Observational Evidence that Great Plains Irrigation Has Enhanced Summer Precipitation Intensity and Totals in the Midwestern United States, J. Hydrometeorol., 16, 1717-1735, 2015.

Biermann, F., Abbott, K., Andresen, S., Bäckstrand, K., Bernstein, S., Betsill, M. M., Bulkeley, H., Cashore, B., Clapp, J., Folke, C., Gupta, A., Gupta, J., Haas, P. M., Jordan, A., Kanie, N., Kluvánková-Oravská, T., Lebel, L., Liverman, D., Meadowcroft, J., Mitchell, R. B., Newell, P., Oberthür, S., Olsson, L., Pattberg, P., Sánchez-Rodríguez, R., Schroeder, H., Underdal, A., Camargo Vieira, S., Vogel, C., Young, O. R., Brock, A., Zondervan, R.: Navigating the Anthropocene: Improving Earth System Governance, Science, 335, 1306-1307, 2012.

Boers, N., Marwan, N., Barbosa, H. M. J., and Kurths, J.: A deforestation-induced tipping point for the South American monsoon system, Sci. Rep.-UK, 7, 41489, https://doi.org/10.1038/srep41489, 2017.

Crowards, T.: Safe minimum standards: costs and opportunities, Ecol. Econ., 25, 303-314, 1998.

Dalin, C., Konar, M., Hanasaki, N., Rinaldo, A., and RodriguezIturbe, I.: Evolution of the global virtual water trade network, P. Natl. Acad. Sci. USA, 109, 5989-5994, 2012.

DeAngelis A., Dominguez, F., Fan, Y., Robock, A., Kustu, M. D., and Robinson, D.: Evidence of enhanced precipitation due to irrigation over the Great Plains of the United States, J. Geophys. Res., 115, D15115, https://doi.org/10.1029/2010JD013892, 2010 .
Destouni, G., Jaramillo, F., and Prieto, C.: Hydroclimatic shifts driven by human water use for food and energy production, Nat. Clim. Change, 3, 213-217, 2013.

Foley, J. A., Coe, M. T., Scheffer, M., and Wang, G.: Regime shifts in the Sahara and Sahel: interactions between ecological and climatic systems in Northern Africa, Ecosystems, 6, 524-539, 2003.

Gawel, E. and Bernsen, K.: What is wrong with virtual water trading? On the limitations of the virtual water concept, Environ. Plann. C, 30, 168-181, 2013.

Gerten, D., Hoff, H., Rockström, J., Jägermeyr, J., Kummu, M., and Pastor, A. V.: Towards a revised planetary boundary for consumptive freshwater use: role of environmental flow requirements, Curr. Opin. Env. Sust., 5, 551-558, 2013.

Goessling, H. F. and Reick, C. H.: What do moisture recycling estimates tell us? Exploring the extreme case of nonevaporating continents, Hydrol. Earth Syst. Sci., 15, 3217-3235, https://doi.org/10.5194/hess-15-3217-2011, 2011.

Guimberteau, M., Laval, K., Perrier, A., and Polcher, J.: Global effect of irrigation and its impact on the onset of the Indian summer monsoon, Clim. Dynam., 39, 1329-1348, https://doi.org/10.1007/s00382-011-1252-5, 2012.

Harding, J. J. and Snyder, P. K.: Modeling the Atmospheric Response to Irrigation in the Great Plains, Part I: General Impacts on Precipitation and the Energy Budget, J. Hydrometeorol., 13, 1667-1686, 2012.

Hoekstra, A. Y.: The Global Dimension of Water Governance: Why the River Basin Approach Is No Longer Sufficient and Why Cooperative Action at Global Level Is Needed, Water, 3, 21-46, https://doi.org/10.3390/w3010021, 2011.

Hoekstra, A. Y. and Hung, P. Q.: Virtual water trade: A quantification of virtual water flows between nations in relation to international crop trade, Value of Water Research Report Series No. 11, Delft, Netherlands, available at: http://waterfootprint.org/media/ downloads/Report11.pdf (last access: June 2017), 2002.

Hoekstra, A. Y. and Mekonnen, M. M.: Reply to Ridoutt and Huang: From water footprint assessment to policy, P. Natl. Acad. Sci. USA, 109, E1425, https://doi.org/10.1073/pnas.1205186109, 2012.

Hoekstra, A. Y., Chapagain, A. K., Aldaya, M. M., and Mekonnen, M. M.: The Water Footprint Assessment Manual Setting the Global Standard, Earthscan, London, Washington DC, available at: http://waterfootprint.org/media/downloads/ TheWaterFootprintAssessmentManual_2.pdf (last access: June 2017), 2011.

Im, E.-S. and Eltahir, E. A. B.: Enhancement of rainfall and runoff upstream from irrigation location in a climate model of West Africa, Water Resour. Res., 50, 8651-8674, 2014.

Im, E.-S., Marcella, M. P., and Eltahir, E. A. B.: Impact of potential large-scale irrigation on the West African Monsoon and its dependence on location of irrigated area, J. Climate, 27, 994-1009, https://doi.org/10.1175/JCLI-D-13-00290.1, 2014.

Jaramillo, F. and Destouni, G.: Comment on "Planetary boundaries: Guiding human development on a changing planet", Science, 348, 1217-1217, 2015.

Jódar, J., Carrera, J., and Cruz, A.: Irrigation enhances precipitation at the mountains downwind, Hydrol. Earth Syst. Sci., 14, 20032010, https://doi.org/10.5194/hess-14-2003-2010, 2010. 
Lee, E., Chase, T. N., Rajagopalan, B., Barry, R. G., Biggs, T. W., and Lawrence, P. J.: Effects of irrigation and vegetation activity on early Indian summer monsoon variability, Int. J. Climatol., 29, 573-581, https://doi.org/10.1002/joc.1721, 2009.

Lewis, S. L.: We must set planetary boundaries wisely, Nature, 485, 417, https://doi.org/10.1038/485417a, 2012.

Mahalov, A., Li, J., and Hyde, P.: Regional Impacts of Irrigation in Mexico and the Southwestern United States on Hydrometeorological Fields in the North American Monsoon Region, J. Hydrometeorol., 17, 2981-2995, 2016.

Meadows, D., Randers, J., and Meadows, D.: Limits to growth: the 30-year update, Chelsea Green, White River Junction, Vermont, USA, 2004.

Micklin, P.: The Aral Sea Disaster, Annu. Rev. Earth Planet. Sci., 35, 47-72, 2007.

Molden, D.: Planetary boundaries: The devil is in the detail, Nature Reports Climate Change, 3, 116-117, https://doi.org/10.1038/climate.2009.97, 2009.

Nordhaus, T., Shellenberger, M., and Blomqvist, L.: The Planetary Boundaries Hypothesis - A Review of the Evidence, The Breakthrough Institute, Oakland, California, available at: http://thebreakthrough.org/archive/planetary_boundaries_a_ mislead, (last access: February 2017), 2012.

Oyama, M. D. and Nobre, C. A.: A new climate-vegetation equilibrium state for tropical South America, Geophys. Res. Lett., 30, 2199, https://doi.org/10.1029/2003GL018600, 2003.

Pei, L. S., Moore, N., Zhong, S. Y., Kendall, A. D., Gao, Z. Q., and Hyndman, D. W.: Effects of Irrigation on Summer Precipitation over the United States, J. Climate, 29, 3541-3558, 2016.

Perry, C.: Water footprints: Path to enlightenment, or false trail?, Agr. Water Manage., 134, 119-125, 2014.

Petschel-Held, G., Schellnhuber, H.-J., Bruckner, T., Tóth, F., and Hasselman, K.: The tolerable windows approach: theoretical and methodological foundations, Clim. Change, 41, 303-331, 1999.

Puma, M. J. and Cook, B. I.: Effects of irrigation on global climate during the 20th century, J. Geophys. Res., 115, D16120, https://doi.org/10.1029/2010JD014122, 2010.

Raffensperger, C. and Tickner, W.: Protecting public health and the environment: implementing the precautionary principle, Island Press, Washington, DC, USA, 1999.

Rockström, J., Steffen, W., Noone, K., Persson, A., Chapin, F. S., Lambin, E. F., Lenton, T. M., Scheffer, M., Folke, C., Schellnhuber, H. J., Nykvist, B., de Wit, C. A., Hughes, T., van der Leeuw, S., Rodhe, H., Sörlin, S., Snyder, P. K., Costanza, R., Svedin, U., Falkenmark, M., Karlberg, L., Corell, R. W., Fabry, V. J., Hansen, J., Walker, B., Liverman, D., Richardson, K., Crutzen, P., Foley, J. A.: Planetary Boundaries: Exploring the Safe Operating Space for Humanity, Ecol. Soc., 14, 32-64, 2009a.

Rockström, J., Steffen, W., Noone, K., Persson, A., Chapin, F. S., Lambin, E. F., Lenton, T. M., Scheffer, M., Folke, C., Schellnhuber, H. J., Nykvist, B., de Wit, C. A., Hughes, T., van der Leeuw, S., Rodhe, H., Sörlin, S., Snyder, P. K., Costanza, R., Svedin, U., Falkenmark, M., Karlberg, L., Corell, R. W., Fabry, V. J., Hansen, J., Walker, B., Liverman, D., Richardson, K., Crutzen, P., Foley, J. A.: A safe operating space for humanity, Nature, 461, 472-475, 2009b.

Scheffer, M., Carpenter, S. R., Foley, J. A., Folke, C., and Walker, B. H.: Catastrophic shifts in ecosystems, Nature, 413, 591-596, 2001.
Steffen W., Richardson, K., Rockström, J., Cornell, S. E., Fetzer, I., Bennett, E. M., Biggs, R., Carpenter, S. R., de Vries, W., de Wit, C. A., Folke, C., Gerten, D., Heinke, J., Mace, G. M., Persson, L. M., Ramanathan, V., Reyers B., and Sörlin, S.: Planetary boundaries: Guiding human development on a changing planet, Science, 347, 1259855, https://doi.org/10.1126/science.1259855, 2015.

The Coca Cola Company: Online Press Release - Coca-Cola on Track to Meet $100 \%$ Water Replenishment Goal, available at: http://www.coca-colacompany.com/press-center/press-releases/ coca-cola-on-track-to-meet-100-water-replenishment-goal (last access: February 2017), 2015.

Tuinenburg, O. A., Hutjes, R. W. A., Stacke, T., Wiltshire, A., and Lucas-Picher, P.: Effects of Irrigation in India on the AtmosphericWater Budget, J. Hydrometeorol., 15, 1028-1050, https://doi.org/10.1175/JHM-D-13-078.1, 2014.

United Nations Environment Programme: Global Environmental Outlook 5, UNEP, Nairobi, Kenya, available at: http://web.unep.org/geo/assessments/global-assessments/ global-environment-outlook-5 (last access: February 2017), 2012.

United Nations Secretary-General's High-Level Panel on Global Sustainability: Resilient People, Resilient Planet: A future worth choosing, New York, United Nations, available at: http://en. unesco.org/system/files/GSP_Report_web_final.pdf (last access: February 2017), 2012.

Van den Belt, H.: Debating the Precautionary Principle: "Guilty until Proven Innocent" or "Innocent until Proven Guilty"?, Plant Physiol., 132, 1122-1126, 2003.

Van der Ent, R. J., Savenije, H. H. G., Schaefli, B., and Steele-Dunne, S. C.: Origin and fate of atmospheric moisture over continents, Water Resour. Res. 46, W09525, https://doi.org/10.1029/2010WR009127, 2010.

Vörösmarty, C. J., Hoekstra, A. Y., Bunn, S. E., Conway, D., and Gupta, J.: Fresh water goes global, Science, 349, 478-479, 2015.

Wichelns, D.: Virtual Water and Water Footprints Offer Limited Insight Regarding Important Policy Questions, Int. J. Water Resour. D., 26, 639-651, 2010.

Wichelns, D.: Assessing Water Footprints Will Not Be Helpful in Improving Water Management or Ensuring Food Security, Int. J. Water Resour. D., 27, 607-619, 2011.

Wichelns, D.: Virtual Water and Water Footprints: Overreaching Into the Discourse on Sustainability, Efficiency, and Equity, Water Altern., 8, 396-414, 2015.

World Wildlife Fund for Nature (WWF): Living Planet Report 2016, Risk and resilience in a new era, WWF International, Gland, Switzerland, available at: http://wwf.panda.org/ about_our_earth/all_publications/lpr_2016/ (last access: February 2017), 2016.

Zhuang, W.: Eco-environmental impact of inter-basin water transfer projects: a review, Environ. Sci. Pollut. R., 23, 12867-12879, 2016.

Zou, J., Xie, Z., Yu, Y., Zhan, C., and Sun, Q.: Climatic responses to anthropogenic groundwater exploitation: a case study of the Haihe River Basin, Northern China, Clim. Dynam., 42, 2125 2145, 2014. 